\title{
Towards a Working Definition and Application of Social Age in International Development Studies
}

\author{
CHRISTINA ROSE CLARK-KAZAK \\ International Studies, York University, Toronto, Canada
}

Final version received April 2008

\begin{abstract}
An emerging body of literature in childhood studies addresses the socially constructed nature of age that varies across time and place. However, despite the robustness of existing theory, few practitioners working in development contexts, where children and young people make up a large percentage of the population, consistently distinguish between biological facts of human development and the social meanings ascribed to different stages in the life cycle. Drawing on feminist theory and practical experiences of 'gender mainstreaming' in development studies, this article proposes and applies a working definition of 'social age' to supplement the prevailing focus on chronological age, embodied in legal definitions of 'the child'.
\end{abstract}

\section{Introduction}

The population in many developing countries is youthful by measures of chronological age. According to the United Nations Population Division (2006), in 2005, people under the age of 20 made up approximately 41 per cent of the population of developing regions, while those under the age of 30 constituted 58 per cent of the developing world. For the least developed countries, the statistics are more striking: 52 per cent under the age of 20 and 70 per cent under the age of $30 .^{1}$ As a result of a growing recognition of this demographic reality, development agencies are beginning to respond with an emerging body of domestic, regional and international law, as well as some child-specific development initiatives. While these are important advancements, they do not adequately take into account social realities in dynamic development contexts.

Drawing on the history of integrating gender issues into development initiatives, I suggest that international development policy, programming and analysis are in a 'children in development' phase. In this article, I will demonstrate that current developing thinking and practice on children and young people repeat some of the

Correspondence Address: International Studies, Glendon Campus, York University, 2275 Bayview Avenue, Toronto, Ontario, M4N 3M6, Canada. Email: cclark-kazak@glendon.yorku.ca 
mistakes of the 'women in development' era of the 1970s. While development agencies increasingly recognise children and young people as important to the development endeavour, they often 'target' them in isolation. There is little recognition that children are already part of development processes, and that they are connected to other generations through relationships and social structures. Therefore, this article develops the concept of 'social age' and illustrates how it can be applied to better recognise and support children's roles in development processes and the implications of these latter processes for intra- and inter-generational relations. The concept of social age is also relevant and important to other stages of the life cycle, including old age. However, the focus of this article is on the ways in which social age analysis can inform and enrich approaches to children and young people in development contexts.

\section{Conceptual Debates: Children and Young People}

International legal standards frame definitions of 'children' in development policy, programming and practice (Cohen, 2002). Under the Convention on the Rights of the Child (CRC), a 'child' is defined as any human being under the age of 18 (United Nations General Assembly, 1989). Regional documents, such as the African Convention on the Rights and Welfare of the Child, adopt similar chronological age definitions. State parties to these conventions have also harmonised domestic legislation with the under-18 definition, sometimes as a condition of development assistance. Specific provisions within international, regional and domestic legal instruments relate other ages to the legality of undertaking activities such as paid employment, marriage and consensual sexual relations (Cohen, 1980). The age of criminal responsibility also varies. In international law, no definition of a 'young person' exists. International legal standards define all individuals under the age of 18 as 'children', after which they are legally considered to be adults. However, some international agencies have developed practical guidelines defining 'youth', usually in terms of chronological age. For example, the United Nations defines 'youth' as people between the ages of 15 and 24, based on the definition provided by the General Assembly for International Youth Year in 1985 (United Nations, n.d.).

The chronological age definition of children and young people, so widely applied in international development policy and practice, has been the subject of many critiques in the academic literature. Scholars argue that it creates an arbitrary dividing line - one's eighteenth birthday - between childhood and adulthood (Cohen, 1980; Freeman, 1983; Ladd, 2002; Rogers, 2003). Moreover, it reflects primarily western legal traditions and traditional psychological development discourses that imply universal and monolithic qualities of childhood and youth (Burman, 1994; Boyden, 1997; Pupavac, 2001; White, 2002). In reality, the experiences of children and young people vary widely in relation to social, political and environmental conditions, and individual characteristics (Kessen, 1981; Ingleby, 1986; Scheper-Hughes and Sargent, 1998). Social psychologists have challenged traditional approaches that promote universality of human development by arguing that social factors are fundamental to, rather than mere variables in, development processes (Rogoff, 1990; Rogoff and Chavajay, 1995; Woodhead, 1997). Historical (Paloczi-Horvath, 1971; deMause, 1974; Ariès, 1979; Cunningham, 1995) and 
ethnographic (Mead, 1929; Benedict, 1935; Mead, 1975; la Fontaine, 1985, 1986; Whiting, 1990) research also indicates that conceptions of childhood and young, and perceptions of socially-appropriate roles for children and young people, vary across time, space and culture. Definitions based on chronological age thus overlook social constructions of childhood and youth: the biological facts of physical development have differing socio-political implications depending on context (James et al., 1998). Such chronological definitions and consequent approaches may thus infantilise people who are socially recognised as having passed childhood and youth in their communities (Tefferi, 2003; Ansell, 2005).

\section{A Working Definition of Social Age}

While these conceptual debates are important for analytical purposes, it is unlikely that development agencies and governments will relinquish the administrative efficiency that chronological definitions imply. Moreover, many child rights advocates and governments have invested political capital in chronological age, having tirelessly worked to ensure that minimum age standards were incorporated into such legally binding documents as the CRC. Perhaps the best known example of this is the age of military recruitment and participation in armed conflict. In the $\mathrm{CRC}$, this was initially set at 15 , in line with practice in many countries. However, through advocacy efforts by groups such as the Coalition to Stop the Use of Child Soldiers, an Optional Protocol to the CRC on the involvement of children in armed conflict was adopted and entered into force. This optional protocol raised to 18 the minimum age for direct participation in hostilities, recruitment into nongovernmental armed groups, and compulsory recruitment by governments. The latter are still permitted to accept voluntary recruits from the age of 16 , but must deposit a binding declaration outlining safeguards for this recruitment (including how it will be genuinely voluntary). This example demonstrates the political rationale behind minimum chronological age standards, often embodied in international law, that cannot be overlooked.

Recognising these practical realities, this article develops an additional, distinct concept to capture the socially constructed nature of relationships amongst people in different stages of physical development. Drawing on feminist theory and the history of gender 'mainstreaming' in international development, I propose the concept of social age as a supplementary perspective to chronological age. This article argues that social age analysis, similarly to gender analysis, must thus be taken into account in development programming even by those agencies adopting and promoting chronological age definitions.

The first important contribution that can be borrowed from feminist theory is the distinction between biological facts of life and social constructions. While 'sex' refers to the biological realities of being male, female or neither, ${ }^{2}$ the concept of 'gender' has been developed to refer to the socially constructed roles attributed to males and females, and the relationships between sexes (Scott, 1986; Kelly-Gadol, 1987; Lorber, 1993; Butler, 2003). However, no similar conceptual distinction exists when considering age and human development. As a result, in development programming, age is too often equated solely with chronological age and stripped of its social meanings. This overlooks the fact that chronological age is itself socially 
constructed - employed primarily as a 'marker' of human development in societies ordered by chronological time. In many other cultures, people do not know their chronological age. Moreover, there is widespread variation in the chronological age at which particular biological processes - such as menstruation, growth of pubic and facial hair, and menopause - occur.

In order to ensure that the social aspects and relationships related to age are adequately recognised and taken into account, we can employ the concept of 'social age' to indicate the socially constructed meanings applied to physical development and roles attributed to infants, children, young people, adults and elders, as well as their intra- and inter-generational relationships (Elder, 1975; Wulff, 1995; James et al., 1998; Lesko, 2001). In this way, social age can be analytically and practically distinguished from biological development in a way similar to the distinction between gender and sex. Returning to gender and queer theory, we must recognise that even biological 'facts of life', such as sex and human development, are still socially variable. In this way, the work of post-Vygotskian development theorists (Rogoff, 1990; Rogoff and Chavajay, 1995; Woodhead, 1997), who have shown how context impacts on biological processes, is important.

The analytical distinction between biological and social age is nonetheless useful for development theory, policy and practice because it helps to move beyond a polarised universal versus social construction debate, focusing instead on the need for a greater understanding of the social meanings ascribed to biological development. In other words, even as development agencies continue to apply the chronological age definition of children (as a proxy for biological development in the absence of individual biological assessments), their programming would benefit from a social age analysis to contextualise their initiatives within particular, localised realities. Just as it is no longer assumed that all women, due to their biology, have the same experiences and roles everywhere, similarly, the application of a 'universal' chronological age definition of childhood should not preclude a social age analysis to determine the differential experiences of children within a particular context.

While some studies use 'generation' instead of, or as a synonym for, social age (Schwartz, 1975; Braungart and Braungart, 1986; Alanen, 1998; Mayall, 2000), this can create conceptual confusion. Generation is a concept with many different meanings in everyday practice (Baxter and Almagor, 1978b; Braungart and Braungart, 1986; Eisenstadt, 2003; Loizos, 2007). It refers to: a) the time span between the birth of an individual and the birth of that individual's offspring; and/ or, a group of people: b) at the same genealogical level (for example mothers and aunts) (Baxter and Almagor, 1978a); c) sharing a similar social status (for example initiands) (Baxter and Almagor, 1978a); d) 'who are bound together by a shared agegroup consciousness' (for example 'Great Depression generation') (Braungart and Braungart, 1986: 217); and/or, e) of the same approximate chronological age (that is coevals) (Stewart, 1977). Despite this variation, implicit in all definitions is the notion of relationship and hence considerations of power. These are important and thus retained in this paper, where 'generation' refers to groups of people sharing infancy, childhood, youth, adulthood and old age at any particular time. This is not to reify assumptions of homogeneity implied by group definitions (Bettelheim, 1963; Braungart and Braungart, 1986; Spencer, 1990; Arnaut, 2005). Indeed, many ethnographic studies show hierarchies within generations based on class, gender, 
birth order, age sets, and so on. (Stewart, 1977; Baxter and Almagor, 1978a; la Fontaine, 1978; Radcliffe-Brown, 1987). We must thus also analyse relationships within generations, with particular attention to the intersectionality of power relations in social contexts (Brenner, 2000). While social age as a concept encompasses these intra- and inter-generational relationships, it also refers to the social meanings and roles ascribed to different stages in the human life cycle. In other words, social age is a broader term that includes but is not limited to generational considerations.

\section{Beyond 'Children in Development' to Social Age Mainstreaming}

The concept of social age not only provides greater analytical clarity; it is also theoretically and practically useful in helping the development community move beyond what I perceive to be a 'children in development' phase. Here, I draw again on parallels in the history of 'gender mainstreaming'. In the 1970s, following the publication of Ester Boserup's research on the gendered division of labour (Boserup, 1970), 'women in development' (WID) emerged in development theory and practice to describe a concern with 'integrating' women into on-going development initiatives (Rathgeber, 1990; Kabeer, 1994). While the WID stage was an improvement on earlier development practices that ignored women altogether, it was critiqued for focusing attention exclusively on women, rather than on gender norms and relationships between women and men. Moreover, WID approaches encouraged greater implication of women in productive work, ignoring the reproductive roles that women already undertook, and thereby contributing to their 'double burden'.

Current development thinking and practice with children and young people reproduces some of the challenges of the WID phase. Young people's issues are often perceived to require specialised knowledge and intervention and hence are 'contracted out' to specific organisations - such as Save the Children, Plan International and the United Nations Children's Fund (UNICEF) - or units within organisations - such as the Child Protection Unit at the Canadian International Development Agency and the Children's Rights Division at Human Rights Watch. These child-specific organisations and initiatives are, of course, important. However, the 'ghettoisation' of child rights and protection issues sometimes results in them being addressed in isolation from, or treated as an 'add-on' to, broader development initiatives. This is apparent in a tendency among child- and/or young people-specific organisations and initiatives to focus on sensationalised categories, such as 'child soldiers', 'street children', 'AIDS orphans' and 'child slaves', rather than framing these issues within their broader development contexts: political violence, urbanisation, poverty, economic exploitation, and so on. As with WID approaches, children and young people are too often perceived to be outside of the development process. Their productive and reproductive roles are integral to families and communities, but are often overlooked or pathologised as interfering with other development ideals, such as formal education (Nieuwenhuys, 1996; Boyden et al., 1998). 'Integrating' children and young people into development initiatives without adequately taking into account their other responsibilities contributes to increasing pressure on children and young people's time. 
To move beyond this 'children in development' thinking, it is useful to draw on the historical lessons learned as the development community progressed from the early WID approach to current 'gender mainstreaming' through gender analysis of development initiatives. In particular, we have moved away from 'woman' as a biologically given category to explore gender as socially constructed. This has also paved the way for greater attention to relationships between and among the sexes, as well as masculinity and homosexuality. Similarly, development policy-makers, practitioners and scholars wishing to promote greater attention to the socially constructed nature of age and the importance of relationships within and between generations can look to promote social age analysis as a way to 'mainstream' these issues within development theory and practice. Just as gender analysis is integral to development planning and implementation, so too should social age analysis be integrated into all development initiatives.

Currently, 'mainstreaming' activities related to children and young people have been undertaken primarily within the context of 'child rights', as set out in the CRC, and as part of broader 'rights-based' approaches to development. Social age mainstreaming is distinct from this child rights mainstreaming approach in several important ways. First, child rights mainstreaming is based on the $\mathrm{CRC}$ and hence a chronological age definition of children. In contrast, social age mainstreaming promotes understanding of localised, socially constructed definitions and roles of children and young people. Second, child rights approaches are focused on children as a particular legal category with specialised rights (Clark, 2007), while social age mainstreaming, with its explicit intra- and inter-generational approach, situates young people in relationships. Finally, child rights mainstreaming takes a universalistic approach, based on legal positivism (Clark, forthcoming), while social age analysis seeks to understand the specificity of particular contexts and relationships.

While I promote social age analysis as a way to ensure that children and young people are considered broadly in development theory and practice, I do recognise some of the short-comings of 'mainstreaming' approaches. In particular, although intended to effect organisational change (Hartsock, 1981), mainstreaming may actually de-politicise radical agendas by incorporating 'language' into technocratic planning and programming without changing the reality on the ground. Moreover, 'social age', like 'gender' before it, can be misinterpreted and applied in counter-productive ways. In a review of gender and age mainstreaming sponsored by the United Nations High Commissioner for Refugees (UNHCR), for example, Groves (2005) argues that gender and age are often perceived in terms of specific projects for 'women' and 'children', rather than as a requirement for over-arching organisational change: 'The wider context of power relations caused by societally defined age and gender roles and their impact on women and children are therefore being missed, as are issues of discrimination faced, for example by young or elderly men, for example' (Groves, 2005: 7). In order for social age analysis to be consistently and appropriately applied, the analytical steps and anticipated benefits must be clearly articulated.

\section{Social Age Analysis in Practice}

This next section thus describes the principal elements of a social age analysis and applies them to the example of development assistance for people from the 
Democratic Republic of Congo (DRC) residing in Kyaka II refugee settlement, western Uganda. Situated in a rural area of Kyenjojo District, Kyaka II is approximately 200 kilometres from both Kampala and Fort Portal (UNHCR, 1983) and accessed only by a dirt road. Ethnographic research presented in this paper was carried out in January to March and October to November 2005. Data were collected using a variety of qualitative methods, including semi-structured interviews, focus group discussions, writing exercises and observation. Snowball and purposive sampling were used to identify approximately 200 research subjects in Kyaka II. Snowball sampling can result in bias towards respondents who share certain characteristics and/or are more visible, thereby undermining representivity (Robson, 1993; Bernard, 1995; Jacobsen and Landau, 2003). Purposive sampling was thus also used to identify multiple entry points into communities and research subjects. Despite time and logistical constraints, the study sought to include young people of different ethnicity, sex, and age, living in different circumstances. I carried out research, without interpretation, in French, English and Swahili. However, my limited Swahili language skills precluded in-depth research with people who did speak some French or English and hence had completed some formal education. There is a consequent bias towards middle class research subjects. All direct quotations in this paper have been translated by me into English.

The first step in social age analysis entails gathering basic demographic information, ${ }^{3}$ including chronological age, biological development indicators such as infant mortality and life expectancy, and marital, familial and employment status (since these are often important social age markers, as discussed below), for the population as a whole, as well as for the specific phenomenon under study. Such ageand development-disaggregated data permit the analyst to understand the relative presence of different age groups and to compare the demographics of the community with other groups. In Kyaka II at the time of research, for example, Government of Uganda statistics indicated that, out of a total Congolese population of 11,880 people, 6456 (or 54\%) were under the age of 18. This is comparable to the demographic situation in the DRC, where UN estimates indicate 58 per cent of the population is under the age of 20 (United Nations Population Division, 2006). ${ }^{4}$ Marital, familial and employment statistics for Kyaka II are unavailable, but would provide a more complete picture of social age dynamics, given the social importance attached to marriage, described below. However, even the existing demographic data provide important insights for development practitioners and researchers. While it is often assumed that women and children make up the majority of the population in refugee camps (Malkki, 1996), in the Kyaka II context, available demographic information suggests that the number of children and young people are actually proportionate to the country of origin.

Second, social age analysis entails an investigation into the social meanings ascribed to biological human development and/or chronological age. What are the culturally-specific definitions of childhood, youth, adulthood and old age? Are there socially-prescribed roles for different generations, that may be codified in norms or laws? Ethnographic research with Congolese in Kyaka II revealed that social roles and activities, including physical development, knowledge, remunerated employment, marriage and parenthood, are 'markers' of childhood, youth and adulthood. While historically in western child development theory, chronological age has been 
linked to particular periods of physical development, for many research subjects physical attributes affect social age. Indeed, in the absence of systematic birth registration, exact chronological ages may not be known. Therefore, research subjects identified as children individuals whom they assume are still 'growing'. For example, when asked to define a child, Nyota $^{5}$ pointed to small girl playing nearby, 'Like this one here.' Others used physical characteristics of sexual maturity to indicate the end of childhood: menstruation and development of breasts for females; vocal change and appearance of facial hair for males.

Related to markers of physical development, research subjects, particularly adults, attributed certain levels of knowledge or intellectual development to different stages in the life cycle. They believed that children are by definition ignorant, young people have more knowledge, and adults, particularly elders, are inherently wise (la Fontaine, 1977). For example, Murhabazi, an older Congolese leader in Kyaka II, defined a child as 'someone who is not yet conscious of what he's doing, who can't form plans'. Similarly, another male elder, considered a child as 'someone who doesn't reason' and a young person as 'someone who doesn't understand'. These socially ascribed characteristics are important in contexts of development assistance where external agencies may attempt to uphold participation rights embodied in the $\mathrm{CRC}$. These participation rights accord children the right to participate in decisions that affect them, which could clash with socially embedded norms that adults, particularly elders, inherently 'know best'. Social age analysis thus allows development practitioners to anticipate and respond to potential challenges to their initiatives.

Many research subjects implicitly or explicitly highlight marriage as a socially significant turning point - especially for males - from youth to adulthood. One elderly man summed up adulthood: 'When a person is big, marries and builds a house.' However, this is gender-specific. Jacqueline, a mother of three, explained: '[Y]outh starts at puberty and goes until you're married. If you're not married, you're not considered an adult and can't sit with the men when they discuss. Normally, we tell a young person that they should find a wife before giving orders.' Although answering a question posed specifically to encompass both sexes ('How do you know when a girl becomes a woman and a boy becomes a man?'), Jacqueline referred only to young males, who can 'sit with the men' after they 'find a wife'. This reflects gendered differential decision-making processes which must be considered in relation to social age. For example, it may indicate that 'youth' is less commonly identified with females than males. This is apparent in the ethnographic literature, which tends to focus on puberty rites for young women and initiation rites for young men (Bettelheim, 1955; Abrahams, 1978; la Fontaine, 1985). In Congolese groups, as in many contexts, gender thus intersects with social age in social relationships based on patriarchy. Understanding these complex and nuanced power relations is another advantage of a social age perspective, especially when compared to chronological assumptions of universal experiences that do not take into account children and young people's multiple subject positions (Mouffe, 1993: 77), including gender, class, ethnicity and religion.

Due to these gender differences, the socio-political implications of procreation, socially acceptable only after marriage among research subjects, is particularly significant for young women. For example, Marthe self-identified as a young person 
'because I have not yet given birth'. Discussions about procreation amongst research subjects were often gendered, with a hypothetical case of a pregnant young woman regularly cited to illustrate the beginning of adulthood, while a sexually active male was never given as an example. This highlights the importance of familial roles associated with adulthood: parenthood accords responsibility and authority over another human being. Olivier explicitly links parenthood and adulthood; he considers himself to be a child 'because I am in the hands of my parents' and selfidentifies as a young person 'because I have not yet had children'.

However, young people who have children before marriage were not necessarily considered adults amongst Congolese in Kyaka II. Since young males may be reluctant to admit paternity, young woman are more likely to be affected by the social implications of premarital reproduction. Unmarried mothers may be stigmatised and treated with less respect than their married counterparts. The implied social statement is that such young women have defied social norms and hence are unsuitable adult role models. Interestingly, this includes female research subjects who have been raped and thus for whom motherhood was not a choice.

The experiences of 16-year-old Salome are illustrative in this regard. She was raped by an opposition force soldier in the DRC, became impregnated and gave birth to a son. In order to avoid the stigma of rape and premarital reproduction, Salome pretends that her son is her younger brother. Her mother registered the baby as her own son on her refugee claim. Salome considers herself to be a young person because 'I haven't yet left home and I'm not married'. She also believes that a young person cannot have had children, thereby further disassociating herself from her son through her self-definition. Salome's relationship towards her son is more of that between siblings. I was unaware of the truth until her mother told me after I had known the family for several months. When I followed up with Salome in October 2005, her 18-year-old friend, Adèle, who had also been raped in the DRC, had recently given birth to a daughter. Adèle was unable to disguise her unmarried motherhood status, since she was pregnant while in Uganda. She lavished attention on her daughter and other girls in the neighbourhood also competed to care for the baby. At this stage, Salome also told me about her own experience of rape and motherhood.

Procreation highlights another way in which children and young people are socially categorised in Kyaka II: in relation to others. The terms 'child' and 'children' do not just refer to people at particular periods in their life, but also familial relationships. An 'adult' is still the 'child' of someone; this is significant given the importance of lineage in Congolese groups. Many research subjects extended kinship terms beyond the nuclear family to other relatives, friends and clan or 'tribe' members. For example, research subjects regularly referred to older Congolese females as 'Mama' ('mother') and males as 'Baba' ('father) or 'Mzee' ('elder'), as titles of respect. This demonstrates the social significance of parenthood within Congolese groups and contradicts one-sided assumptions of children's 'dependence' and 'vulnerability', commonly upheld in development theory and practice (Clark, 2007). Adults also need children for their economic roles and the social status of parenthood (Tolfree, 2004). Similarly, the term 'children' is not simply reserved for people of a particular chronological age, but rather to designate people who are 
younger than the speaker to whom they are endeared. Some of the older Congolese in this study, for example, called me mwanangu, literally 'my child'.

This analysis of social age reveals a general consensus amongst research subjects about experiencing puberty as a biological fact, which occasions possibilities of reproduction and hence the end of childhood. This corresponds to ethnographic literature on groups in eastern DRC, which historically celebrated puberty rites. Circumcision for young males (Southall, 1955; Turnbull, 1961) and the onset of menarche for young females (Turnbull, 1961; la Fontaine, 1985) signify the end of childhood for individuals, which is then celebrated collectively, often in cohorts. However, such puberty rites, which mark a natural change, are distinguished from, and do not necessarily coincide with, rites of initiation into adulthood, which mark a social change (la Fontaine, 1985). This indicates that groups in eastern DRC have historically had a transitional youth stage between childhood and adulthood, which varies in time and significance, especially across gender (Maquet, 1961; la Fontaine, 1985; Burman, 1986; Whiting, 1990; Newman, 1996).

For research subjects, marriage is the most socially significant marker of adulthood, a trend also apparent in ethnographic literature (la Fontaine, 1970; Grinker, 1994; Gondola, 1999). Marriage does not necessarily mean that individuals, especially females, have full and equal adult roles. However, it does provide them with a socially accepted reason for a 'roof of their own' (Woolf, 1929) - physically or metaphorically - which has important implications for control over resources and decision-making in family and household networks (Clark, 2006b). This social significance of marriage is also demonstrated by unmarried young people in peer networks, who do not self-identify as adults even though they play primary decisionmaking roles in household networks. These include young people who refer to younger siblings and relatives as 'children', 'even though they are really young people, because they are in my home and I feel like their mother'.

Social age analysis thus provides important contextualised meanings of childhood and youth to supplement legal definitions based on chronological age. For the majority of Congolese in Kyaka II, the terms 'child' and 'children' refer to all individuals who have not yet reached puberty. 'Young people' are post-pubescent individuals who have not yet married. These context-specific understandings of social age should be regularly sought out to complement 'universal' definitions based on chronological age. Such an approach will enable development practitioners, analysts and policy-makers to ensure that interventions are based on local realities of childhood, youth, adulthood and old age.

A third element of social age analysis entails an exploration into how biological differences related to physical development may affect differential experiences and impacts of development initiatives for children, young people, adults and elders. In Kyaka II, for example, the Self-Reliance Strategy (SRS) requires refugees to farm in order to survive. Launched in 1998 as a joint initiative between UNHCR and the Government of Uganda (GoU) in response to protracted refugee situations (UNHCR and OPM, 1998), the SRS was conceived as a way to bridge the 'reliefdevelopment gap' by providing refugees with the means to support themselves through subsistence agriculture, thereby reducing their dependency on food aid (OPM and UNHCR, 1999). Once registered in Kyaka II, refugees are allocated plots of land, on which they grow subsistence crops. Rations are gradually reduced and 
eventually phased out to promote self-reliance. This policy is applied to everyone, without regard to physical ability to undertake farming. A social age analysis exploring the physical realities of human development demonstrates that the selfreliance strategy disproportionately discriminates against the very young and the very old. It also penalises people with disabilities, those with chronic illnesses and nursing mothers. As Tolérance noted, 'Those people there [in the refugee offices] have no pity for refugees. Even when I came here, I was in very bad condition. They gave me the forest and told me to farm. If I hadn't found the family I am staying with, I don't know what would have happened.'

Fourth, social age analysis involves an analysis of the generational division of labour. Productive and reproductive roles will also be informed by other subject positions (Mouffe, 1993), particularly gender and class. The division of labour is important in understanding power structures within a given community, as well as the differential opportunities and time available to participate in various development activities. In Kyaka II, most children undertake a variety of reproductive roles, which are usually non-remunerated and often under-valued, even by children and young people themselves. For example, Adèle declared, 'Children don't work.' But, she later described her younger siblings' chores, including washing, laundry and meal preparation. Similarly, when discussing the allocation of tasks in her peer household network, Catherine described younger peers' activities as 'domestic chores ... children's work'. While young people, especially females, often did not explicitly recognise their own work and responsibilities, this issue did arise implicitly in their ambiguous self-definition. For example, Danielle struggled to self-identify as a child or young person, but finally resolved that she was a child because 'I don't do anything.' Despite her stated idleness, Danielle is responsible for domestic tasks in her adoptive family.

A social age analysis into the division of labour in Kyaka II also helps to explain the seemingly contradictory fact that young people who lived without their parents or an adult caregiver (often referred to as 'unaccompanied minors') were disproportionately represented in the secondary school in the settlement. The young people in this study who lived in peer groups generally had a greater amount of leisure time and control over independent economic resources than those living in intergenerational households. In intergenerational households, labour was much more likely to be unpaid, as all members of a household were expected to contribute to collective wellbeing. Any income that they earned outside the home was handed over to the head of household for collective consumption. For example, in a focus group discussion with students, they said that once the crops they plant are harvested, it is heads of household who receive money from the crops and use it to 'to buy the needs of the family'. Moreover, since these young people were usually listed as 'dependents' on the head of household's claim, any assistance, benefits, and, indeed, legal status were accorded to the principal claimant. This solidified and entrenched the status of the 'head of household' and the assumed dependency relationship of younger and/or female 'others'. The household head was thus responsible for distributing collective resources within the family and, due to social hierarchies based on social age and gender, young people (particularly female and those who were not the biological offspring of the head of household) were often given less than an equal share. 
In contrast, young people living on their own or in peer groups were more likely to obtain individual, concrete benefits from any labour they undertook. While groups of such young people often worked together in their respective plots of land, the yields and any economic benefits were usually distributed amongst them depending on the amount of labour they had put in. Moreover, those who undertook work for other people (such as working in fields) were remunerated for their labour in cash or in kind, albeit often at a very low rate. Finally, young people registered by themselves received rations as individuals and hence had more control over their individual portions, which they often then chose to pool with others. This meant that young people living on their own had more time and independent economic resources to invest in educational activities.

Antoinette's experiences are illustrative with respect to reproductive labour. Originally from Ituri, eastern Congo, she came to Uganda when she was seven years old to attend primary school in Rwebisengo, close to the Congolese border. Her parents sent her to live with her paternal uncle and family and paid the latter for her school fees and living expenses. During school holidays, Antoinette would return to her parents' home in Ituri, until her parents were killed in the armed conflict. Following their death, Antoinette's uncle could not afford to keep her, so he took her to Kyaka II refugee settlement, where she registered as an unaccompanied minor. While in the settlement, Antoinette met her maternal aunt and lived with them until they decided to return to the DRC. Antoinette wanted to stay in Kyaka II to complete her education at the secondary school there, so she built a hut with some other students, whom she now lives with.

In comparing her experiences in the three different living arrangements, Antoinette identified differences in food, studies and work. In Rwebisengo, she ate rice, posho (a porridge made of maize meal), potatoes and milk. In Kyaka II, both with relatives and peers, she eats 'maize and beans throughout each month'. In terms of education, she feels that the quality in Kyaka II is not as good as in Rwebisengo. In comparing work loads, she had more tasks in intergenerational arrangements than with other peers. In the former arrangements, Antoinette spent three hours a day on domestic tasks, including cleaning, sweeping, milling, fetching firewood and water, and preparing food. With her peers, 'Each one has to perform his or her duty.' Antoinette is responsible for sweeping the compound and rooms, fetching water and preparing food on alternate days. These tasks take her an hour in the morning and about two hours at night when she is responsible for the chores. On alternate days, Antoinette is free to do as she likes. 'Now that I am living with the group, I have more time to spend on my studies.'

An analysis of the division of labour within and between generations, as illustrated by Antoinette's case, thus provides a greater understanding of how children, young people, adults and elders use their time in development contexts, and whether they are compensated individually or collectively for their labour. Such information can help development workers ensure that their initiatives are accessible to a greater number of people. It can also help to reduce the potentially negative indirect effects of adult-focused activities on children. For example, in Kyaka II, women who found remunerated employment in camp employees' homes or in development initiatives sometimes withdrew their children, particularly girls, from school, so that the latter could take care of unremunerated reproductive tasks for the family. 
Finally, social age analysis requires an analysis of dynamic intra- and intergenerational relationships. In many cases, the development context or intervention itself may provoke changes in these relationships. For example, in Kyaka II, some Congolese women argued that refugee life had had a negative effect on children and young people because young people now do not show respect to their elders. Parents cannot fulfil their needs, so they do not have authority over their children. Indeed, some young subjects directly or indirectly revealed that parents were not fulfilling their expected roles. For example, Bahati discussed the problem of school fees, which many parents cannot afford. As a result, students are sent home and have to work to make money for school fees themselves. These findings relate to Mann's research with Congolese children and young people in Dar es Salaam, who felt that parents were falling short of their responsibilities (Mann, 2003a,b).

The context of prolonged displacement in Kyaka II also impacted on perceptions of social age, with important differences based on class. For middle class research subjects, displacement prolonged the period of youth because they become relatively worse off and hence could not afford to continue their education and/or marry. Young males more often cited the economic cost and responsibilities of marriage than their female counterparts. For example, when asked if he wanted to get married, Déogratius replied, 'Even for myself, I don't have enough to eat.' Many self-identified 'intellectuals' expressed frustration at this prolonged youthful status. Paul cannot fulfil 'normal' social functions of marriage because he does not have the economic means. After describing his circumstances one day, Paul added, 'And I don't even have a wife to comfort me.' He only 'look[s] like a child' (a reference to his small physical size); if he were in the DRC, he would have married and had children by now.

In contrast, some research subjects from poor socio-economic backgrounds viewed marriage as a socially accepted option in contexts of limited choices. In Kyaka II, once young men reaped their first harvest on their allocated plots of land, they deemed their position stable enough to marry. For example, 18-year-old Gaston has never studied and cites education as a hope for the future. However, due to limited options in Kyaka II, he has instead decided to get married: 'Even now, if possible.' Parents may encourage unions since brides' families receive a dowry (in the form of goods or money) and grooms' families gain domestic labour. Others suggest that marriage amongst people from poorer socio-economic backgrounds also occurs at a lower age in the DRC: 'You get cattle, and there are fewer expenses at home. As they say, 'One less mouth to feed.' Young people get married even though the girl is only 15 or 16 since people here [in Kyaka II] suffer so much.'

Perceptions of young people and their social roles are also affected by exposure to western norms and values in development contexts. With colonisation, westernisation and urbanisation, formal education has also become an important indicator of social age, as well as socio-economic status. For example, in Kyaka II, students in primary school, even if they are much older than 'normal' for classes, are often referred to, and self-define as, children. In contrast, most secondary students selfidentify as young people, even if they are chronologically younger than their counterparts in primary school. Exposure to 'child rights sensitisation' and international aid prioritising children and young people also contributes to evolving self-identification. Some research subjects, particularly students and self-proclaimed 
'human rights activists', use age-based definitions of children and young people, although these vary widely. For example, in an informal discussion with Congolese of different ages and sexes from different backgrounds, Ron said, 'In African cultures, youth starts at 15 and ends at 45.' Marie argued that it was different in different countries: in DRC, childhood is from birth to age 13; youth is 13 to 40; and 'old age' begins at 40. Later in the discussion another young male said that 'youth' is from 7 to 77, while the 'youngest youth' are aged 17 to 40 . Another suggested further categorisation: 1 to 5 as small children, and 5 to 17 as children. These variations in chronological age definitions contrast with convergence on social markers, discussed above, and thus provide further evidence of the usefulness of supplementing chronological age definitions with social age analysis.

The tendency of international aid organisations to designate 'children' as categories for priority assistance (Clark 2007) contributes to ambiguity and posturing in self-identification. Even research subjects who subscribe to social definitions of childhood, youth and adulthood, sometimes choose to self-identify as 'young people' in order to qualify for priority assistance. For example, Sara, who is a single mother, self-identifies as an adult, but recognises the political efficacy of presenting herself as a 'young person': 'Although I have given birth, I am still young.'

Displacement also caused changes in intra- and inter-generational relationships. One significant development is the advent of groups of young people living on their own without older generations present, as illustrated by Antoinette's story above. This is a fairly recent phenomenon, resulting from social change against the backdrop of conflict and displacement in the DRC (de Boeck, 2005). Within these peer networks, young people developed complex hierarchical intra-generational relationships based on gender, level of education, access to resources and length of residence in Kyaka II (Clark, 2006a). Social age analysis thus allows a more nuanced understanding of differential experiences based on specific contexts and relationships, rather than assuming homogeneity within generations.

\section{Conclusion}

This example from Kyaka II demonstrates the richness of data and depth of understanding yielded by social age analysis. While recognising the legal and normative underpinnings, administrative efficiency and political rationale of the chronological age definition, I argue that social age analysis allows practitioners, policy-makers and analysts to contextualise children and young people's experiences within broader social, economic and political processes. This moves away from assumptions of universality and homogeneity implied in chronological age definitions. It will also assist in overcoming some of the shortcomings of the current 'children in development' approach. Rather than considering children and young people in isolation, we need to take into account inter- and intra-generational power relations. Similarly, in addition to child- and youth-specific initiatives, all development processes should be analysed with a view to understanding the differential experiences of, and impact on, children, young people, adults and elders.

As demonstrated in the application of social age analysis to development programming in Kyaka II refugee settlement above, this shift from 'children in 
development' to social age mainstreaming will have several positive practical consequences for aid agencies. First, development practitioners and policy-makers will better understand localised constructions of childhood, youth and adulthood and the roles ascribed to different generations. This understanding, in turn, will assist them in ensuring that development interventions are sensitive and relevant to these particular contexts, thereby increasing the chances for sustainable development results. Second, by analysing intra- and inter-generational relationships and division of labour within particular contexts, development agencies will be more aware of the potential negative effects their interventions could have on individuals and groups who are not explicitly 'targeted' by their initiatives. They can consequently reorient their programming to ensure that the costs and benefits of development initiatives are more evenly distributed amongst different generations. Finally, social age analysis aids in identifying power relationships within families and communities, upon which development workers can both capitalise and manage in their efforts to effect positive change.

\section{Notes}

1. 'Less developed regions' are defined as 'all regions of Africa, Asia (excluding Japan), Latin America and the Caribbean plus Melanesia, Micronesia and Polynesia'; 'The group of least developed countries, as defined by the United Nations General Assembly in 2003, comprises 50 countries, of which 34 are in Africa, 10 in Asia, one in Latin America and the Caribbean, and five in Oceania.' See: United Nations Population Division 2006.

2. It should be noted that some gender and queer theorists have critiqued the assumed biological meanings ascribed to sex. Moreover, anthropologists have document the existence of a 'third sex' in many cultures (Goulet, 1996).

3. This may require relying on government or United Nations data, which is not always accurate. However, age-disaggregated data can provide a snapshot of demographic trends.

4. UN information is disaggregated into five-year sections, while Government of Uganda statistics are disaggregated into 0-4 years and 5-17 years, so it is not possible to compare the data exactly.

5. All names have been changed.

\section{References}

Abrahams, R.G. (1978) Aspects of Labwor age and generation grouping and related systems, in: P.T.W Baxter and U. Almagor (eds) Age, Generation and Time: Some Features of East African Age Organisations (London: C. Hurst and Co.).

Alanen, L. (1998) Children and the family order: constraints and competencies, in: I. Hutchby and J. Moran-Ellis (eds) Children and Social Competence: Arenas of Action (London: Falmer Press).

Ansell, N. (2005) Children, Youth and Development (London and New York: Routledge).

Ariès, P. (1979) Centuries of Childhood (Harmondsworth: Penguin).

Arnaut, K. (2005) Re-generating the nation: youth, revolution and politics of history in Cote d'Ivoire, in: J. Abbink and I. Van Kessel, I. (eds) Vanguard or Vandals: Youth, Politics and Conflict in Africa (Leiden: Brill).

Baxter, P.T.W. and Almagor, U. (1978a) Introduction, in: P.T.W. Baxter and U. Almagor (eds) Age, Generation and Time: Some Features of East African Age Organisations (London: C. Hurst \& Co).

Baxter, P.T.W. and Almagor, U. (1978b) Observations about generations, in: J. La Fontaine (ed.) Sex and Age as Principles of Social Differentiation (London: Academic Press).

Benedict, R. (1935) Patterns of Culture (London: Routledge \& Kegan Paul Ltd.).

Bernard, H.R. (1995) Research Methods in Anthropology: Qualitative and Quantitative Approaches (Walnut Creek: Alta Mira Press).

Bettelheim, B. (1955) Symbolic Wounds: Puberty Rites and the Envious Male (London: Thames and Hudson). 
Bettelheim, B. (1963) The problem of generations, in: E. Erikson (ed.) Youth: Change and Challenge (New York: Basic).

Boserup, E. (1970) Woman's Role in Economic Development (London: Allen and Unwin).

Boyden, J. (1997) Childhood and the policy makers: A comparative perspective on the globalization of childhood, in: A. James and A. Prout (eds) Constructing and Reconstructing Childhood. 2nd ed. London: Falmer Press.

Boyden, J., Ling, B. and Myers, W. (1998) What Works for Working Children (Stockholm: Save the Children Sweden).

Braungart, R. and Braungart, M. (1986) Life-course and generational politics. Annual Review of Sociology, 12 , pp. 205-231.

Brenner, J. (2000) Women and the Politics of Class (New York: Monthly Review Press).

Burman, E. (1994) Innocents abroad: western fantasies of childhood and the iconography of emergencies. Disasters, 18, pp. 238-253.

Burman, S. (1986) The contexts of childhood in South Africa: an introduction, in: S. Burman and P. Reynolds (eds) Growing $U p$ in a Divided Society: Contexts of Childhood in South Africa (Johannesburg: Raven Press).

Butler, J. (2003) Performative acts and gender constitution: an essay in phenomenology and feminist theory, in: C. McCann, and S.-K. Kim (eds) Feminist Theory Reader: Local and Global Perspectives (New York and London: Routledge).

Clark, C. (2006a) Beyond borders: Political marginalization and lived experiences of Congolese young people in Uganda. PhD thesis, Oxford, Oxford University.

Clark, C. (2006b) Livelihood networks and decision-making among Congolese young people in formal and informal refugee contexts in Uganda. Households in Conflict Network, Institute of Development Studies, University of Sussex, Brighton.

Clark, C. (2007) Understanding vulnerability: from categories to experiences of Congolese young people in Uganda. Children and Society, 21, pp. 284-296.

Clark-Kazak, C. (Forthcoming) The politics of protection: aid, human rights discourse and power relations in Kyaka II settlement, Uganda. Disasters.

Cohen, C. (2002) United Nations Convention on the Rights of the Child: developing international norms to create a new world for children, in: K. Alaimo, and B. Klug (eds) Children as Equals: Exploring the Rights of the Child (Lanham, Maryland: University Press of America), pp. 49-72.

Cohen, H. (1980) Equal Rights for Children (Totowa, NJ: Littlefield, Adams and Co.).

Cunningham, H. (1995) Children and Childhood in Western Society since 1500 (London: Longman).

De Boeck, F. (2005) The divine seed: children, gift and witchcraft in the Democratic Republic of Congo, in: A. Honwana and F. De Boeck (eds) Makers and Breakers: Children and Youth in Postcolonial Africa (Oxford: James Currey), pp. 188-214.

DeMause, L. (1974) The evolution of childhood, in: L. Demause (ed.) The History of Childhood: The Evolution of Parent-Child Relationships as a Factor in History (London: Souvenir Press), pp. 1-52.

Eisenstadt, S.N. (2003) From Generation to Generation (New Brunswick and London: Transaction Publishers).

Elder, G. (1975) Age differentiation and the life course. Annual Review of Sociology, 1, pp. 165190.

Freeman, M. (1983) The Rights and Wrongs of Children (London: Frances Pinter).

Gondola, C.D. (1999) Dream and drama: the search for elegance among Congolese youth. African Studies Review, 42, pp. 23-48.

Goulet, J.-G. (1996) The 'Berdache'/'two-spirit': a comparison of anthropological and native constructions of gendered identities among Northern Athapaskans. The Journal of the Royal Anthropological Institute, 2, pp. 683-699.

Grinker, R.R. (1994) Houses in the Rainforest: Ethnicity and Inequality among Farmers and Foragers in Central Africa (London: University of California Press).

Groves, L. (2005) UNHCR's Age and Gender Mainstreaming Pilot Project 2004. Synthesis Report. UNHCR, Geneva.

Hartsock, N. (1981) Political change: two perspectives on power, in: N. Benevento (ed.) Building Feminist Theory: Essays from Quest (New York and London: Longman), pp. 3-19.

Ingleby, D. (1986) Development insocial context, in: M. Richards and P. Light (eds) Children of Social Worlds (Cambridge: Polity Press), pp. 297-315. 
Jacobsen, K. and Landau, L. (2003) Researching Refugees: Some Methodological and Ethical Considerations in Social Science and Forced Migration (Geneva: UNHCR).

James, A., Jenks, C. and Prout, A. (1998) Theorizing Childhood (Cambridge: Polity Press).

Kabeer, N. (1994) Reversed Realities: Gender Hierarchies in Development Thought (London: Verso).

Kelly-Gadol, J. (1987) The social relations of the sexes: methodological implications of women's history, in: S. Harding (ed.) Feminism and Methodology (Bloomington and Indianapolis: Indiana University Press), pp. 15-27.

Kessen, W. (1981) The child and other cultural inventions, in: F. Kessel, and A. Siegel, (eds) The Child and Other Cultural Inventions (New York: Praeger).

La Fontaine, J. (1977) The power of rights. Man, 12, pp. 421-437.

La Fontaine, J. (1978) Introduction, in: J. La Fontaine (ed.) Sex and Age as Principles of Social Differentiation (London: Academic Press), pp. 1-18.

La Fontaine, J. (1985) Initiation: Ritual, Drama and Secret Knowledge Across the World (Harmondsworth: Penguin Books).

La Fontaine, J. (1986) An anthropological perspective on children in social worlds, in: M. Richards and P. Light (eds) Children of Social Worlds (Cambridge: Polity Press), pp. 11-27.

La Fontaine, J.S. (1970) City Politics: A Study of Leopoldville, 1962-63 (Cambridge: Cambridge University Press).

Ladd, R.E. (2002) Rights of the child: a philosophical approach, in: K. Alaimo and B. Klug (eds) Children as Equals: Exploring the Rights of the Child (Lanham, Maryland: University Press of America), pp. 89-105.

Lesko, N. (2001) Act Your Age! A Cultural Construction of Adolescence (London: RoutledgeFalmer).

Loizos, P. (2007) 'Generations' in forced migration: towards greater clarity. Journal of Refugee Studies, 20, pp. 193-209.

Lorber, J. (1993) Believing is seeing: biology as ideology. Gender and Society, 7, pp. 568-581.

Malkki, L. (1996) Speechless emissaries: refugees, humanitarianism, and dehistoricization. Cultural Anthropology, 11, pp. 377-404.

Mann, G. (2003a) Not seen or heard: the lives of separated refugee children in Dar es Salaam. Save the Children Sweden, Stockholm.

Mann, G. (2003b) 'We are not here': conducting research with Congolese children and families in Dar Es Salaam. Adolescents and Armed Conflict Seminar Series (Oxford: Refugee Studies Centre, Oxford University).

Maquet, J. (1961) The Premise of Inequality: A Study of Political Relations in a Central African Kingdom (London: Oxford University Press).

Mayall, B. (2000) Conversations with children: working with generational issues, in: P. Christensen and A. James (eds) Research with Children: Perspectives and Practices (London: Falmer Press), pp. 109-125.

Mead, M. (1929) Coming of Age in Samoa: A Psychological Study of Primitive Youth for Western Civilisation (London: Jonathan Cape).

Mead, M. (1975) Children's play style: potentialities and limitations of its use as a cultural indicator. Anthropological Quarterly, 48, pp. 157-181.

Mouffe, C. (1993) The Return of the Political (London: Verso).

Newman, T. (1996) Rights, rites and responsibilities: the age of transition to the adult world, in: H. Roberts and D. Sachdev (eds) Young People's Social Attitudes: Having Their Say - The Views of 12-19 Year Olds (Ilford: Barnardo's), pp. 5-19.

Nieuwenhuys, O. (1996) The paradox of child labor and anthropology. Annual Review of Anthropology, 25 , pp. $237-251$.

OPM and UNHCR (1999) Self-reliance for refugee hosting areas in Moyo, Arua and Adjumani Districts, 1999-2003. Strategy Paper. OPM and UNHCR, Kampala.

Paloczi-Horvath, G. (1971) Youth Up in Arms: A Political and Social World Survey, 1955-1970 (London: Weidenfeld and Nicolson).

Pupavac, V. (2001) Misanthropy without borders: the international child rights regime. Disasters, 25, pp. 95-112.

Radcliffe-Brown, A.R. (1987) Introduction, in: A.R. Radcliffe-Brown and D. Forde (eds) African Systems of Kinship and Marriage. International African Institute ed. (London: KPI), pp. 1-84.

Rathgeber, E.M. (1990) WID, WAD, GAD: trends in research and practice. The Journal of Developing Areas, 24, pp. 489-502. 
Robson, C. (1993) Real World Research: A Resource for Social Scientists and Practitioner-Researchers (Oxford: Blackwell).

Rogers, W. (2003) What is a child? in M. Woodhead and H. Montgomery (eds) Understanding Childhood: A Multidisciplinary Approach (Milton Keynes: Open University), pp. 1-23.

Rogoff, B. (1990) Apprenticeship in Thinking: Cognitive Development in Social Context (Oxford: Oxford University Press).

Rogoff, B. and Chavajay, P. (1995) What's become of research on the cultural basis of cognitive development? American Psychologist, 50, pp. 859-877.

Scheper-Hughes, N. and Sargent, C. (1998) Introduction: the cultural politics of childhood, in: N. ScheperHughes and C. Sargent (eds) Small Wars: The Cultural Politics of Childhood (Berkeley: University of California Press).

Schwartz, T. (1975) Relations among generations in time-limited cultures. Ethos, 3, pp. 309-322.

Scott, J.W. (1986) Gender: a useful category of historical analysis. The American Historical Review, 19, pp. $1053-1075$.

Southall, A. (1955) Alur Society: A Study in the Processes and Types of Domination (Cambridge: W. Heffer and Sons).

Spencer, P. (1990) The riddled course: theories of age and its transformations, in: P. Spencer (ed.) Anthropology and the Riddle of the Sphinx: Paradoxes of Change in the Life Course (London: Routledge), pp. 1-26.

Stewart, F.H. (1977) Fundamentals of Age-Group Systems (London: Academic Press).

Tefferi, H. (2003) Reconstruction of Adolescence in Conflict Situations: Experience from East Africa Adolescents and Armed Conflict Seminar Series (Oxford: Refugee Studies Centre, Oxford University).

Tolfree, D. (2004) Whose Children? Separated Children's Protection and Participation in Emergencies (Stockholm: Save the Children).

Turnbull, C. (1961) The Forest People (London: Jonathan Cape).

UNHCR (1983) Reconnaissance survey of the proposed site for the Kyaka rural settlement for Rwandese refugees in Uganda, 20-26 June 1983. UNHCR, Geneva.

UNHCR and OPM (1998) Refugee Self-Reliance in Northern Uganda: Sharing Land, Services and Responsibilities (Kampala: UNHCR).

United Nations (n.d.) Youth at the United Nations, accessed at http://www.un.org/esa/socdev/unyin/ ganda.htm (accessed 14 January 2008).

United Nations General Assembly (1989) Convention on the Rights of the Child. 61st plenary meeting, A/RES/44/25.

United Nations Population Division (2006) World Population prospects: the 2006 revision population database, accessed at http://esa.un.org/unpp/index.asp?panel=2 (accessed 14 January 2008).

White, S. (2002) From the politics of poverty to the politics of identity? Child rights and working children in Bangladesh. Journal of International Development, 14, pp. 725-735.

Whiting, J. (1990) Adolescent rituals and identity conflicts, in: J. Stigler, R. Shweder, and G. Herdt (eds) Cultural Psychology: Essays on Comparative Human Development (Cambridge: Cambridge University Press), pp. 357-365.

Woodhead, M. (1997) Psychology and the cultural construction of children's needs, in: A. James and A. Prout (eds) Constructing and Reconstructing Childhood. 2nd ed. (London: Falmer Press), pp. 63-84.

Woolf, V. (1929) A Room of One's Own (London: Hogarth Press).

Wulff, H. (1995) Introducing youth culture in its own right: the state of the art and new possibilities, in: V. Amit-Talia and H. Wulff (eds) Youth Cultures: A Cross-cultural Perspective (London and New York: Routledge), pp. 1-16. 